\title{
Pharmacological Effects of Statins Related to Gap Junction Modulation
}

\author{
Lili Qu1 ${ }^{1}$, Jiandong Jiang1* ${ }^{*}$, Weijia Kong2* \\ ${ }^{1}$ State Key Laboratory of Bioactive Natural Products and Function, Institute of Materia Medica, Chinese \\ Academy of Medical Sciences and Peking Union Medical College, Beijing, China \\ ${ }^{2}$ Department of Pharmacology, Institute of Medicinal Biotechnology, Chinese Academy of Medical Sciences and \\ Peking Union Medical College, Beijing, China \\ Email: ${ }^{*}$ iian-dong-jiang@sohu.com, ${ }^{*}$ wjkong894@163.com
}

Received 10 February 2014; revised 11 March 2014; accepted 21 March 2014

Copyright (C) 2014 by authors and Scientific Research Publishing Inc.

This work is licensed under the Creative Commons Attribution International License (CC BY). http://creativecommons.org/licenses/by/4.0/

(c) (i) Open Access

\begin{abstract}
3-Hydroxy-3-methylglutaryl coenzyme A (HMG-CoA) reductase inhibitors, or "statins", are widely using cholesterol-lowering drugs with pleiotropic pharmacological effects. In this review, we summarized the pharmacological effects of statins related to gap junction modulation. The main function of cellular gap junctions, which are composed of trans-membrane proteins named connexins (Cxs), is to mediate direct cell-to-cell communication through material exchange. Statins could rectify the disturbed expression, distribution, or phosphorylation of Cxs and thus modify the functions of gap junctions in a variety of tissues like the aorta, cardiomyocytes, or tumors. The effects of statins on Cxs and gap junctions were associated with their pharmacological activities against atherosclerosis, arrhythmias, and tumors. Despite some evidences suggested that the anti-inflammatory or HMG-CoA reductase inhibiting effects of statins may contribute in part to the modulation of Cxs and gap junctions, the detailed underlying mechanisms are largely unrevealed and merit further investigation. In addition, it is likely that the modulating effects of statins on gap junctions may also contribute to their pharmacological activities against some diabetic complications. Future studies of these issues will help to provide scientific evidences for the appropriate clinical application of statins.
\end{abstract}

\section{Keywords}

Statin; Connexin; Gap Junction; Atherosclerosis; Arrhythmia; Bystander Effect

\footnotetext{
${ }^{*}$ Corresponding authors.
} 


\section{Introduction}

It is well known that in multicellular organisms, crosstalks and communications among cells are of pivotal importance, either for the growth and differentiation, or for the metabolism of organisms [1]-[6]. Communications of cells could be achieved through non-physical or physical manners. Non-physical communications of cells are usually mediated by the actions of hormones or cytokines. Physical communications rely on direct contact or junction of cells. Multiple types of cell junctions are discovered, which include desmosome, adherens junction, tight junctions, gap junction, tunneling nanotube, and so on [1]-[6]. These junctions are found to play important roles in maintaining normal cellular functions [1]-[6].

Gap junctions, which were first discovered in the 1960s [7], are composed of trans-membrane proteins named connexins (Cxs) [5]. Currently, there are 21 different Cxs discovered in humans [5] [8]. Six Cxs of the same kind or different kinds could assemble in subcellular apartments to form a connexon (or hemichannel), which contains a central gap of about $2 \mathrm{~nm}$ [5] [8]. Connexons could be transported to cell surface, where they could couple with counterparts on the surface of other cells to form gap junctions [5] [8].

Cxs are expressed in a variety of mammal cell types [5] [8]. The key function of Cxs and gap junctions is to mediate direct cell-to-cell communication. Adjacent cells could exchange ions, second messengers, metabolites as well as nutrients of low molecular weight via gap junctions [5] [8]-[10]. Alternatively, uncoupled connexons (or hemichannels) on cell surface could facilitate the exchange of materials between cells and extra-cellular matrix [5] [8]-[10].

Cxs and gap junctions play important roles in cell division, differentiation, adhesion, migration and death [5] [8]-[11]. Notably, recent results proved that dysfunctions of Cxs and gap junctions may be related to the development of several human diseases of significant clinical importance, such as coronary heart disease, diabetes, cardiac hypertrophy and arrhythmia, as well as cancer [12]-[17]. Accordingly, the study of gap junction biology has gained great attention in recent years.

3-Hydroxy-3-methylglutaryl coenzyme A (HMG-CoA) reductase inhibitors, or "statins” (Figure 1), are the most widely prescribed lipid-modifying drugs around the world. Statins are potent in lowering low-density lipoprotein (LDL) cholesterol and are effective in reducing cardiovascular events [18]. Numerous studies indicated that statins have pleiotropic pharmacological effects beyond their cholesterol-lowering activity, which may include direct beneficial effects on atherosclerotic plaque, immunomodulatory and anti-inflammatory effects, anti-cancer activities, antiarrhythmic effects, as well as beneficial effects against osteoporosis, Alzheimer's disease, and so on [19] [20].

Although detailed mechanisms underlying the intriguing activities of statins remain controversial and need further investigation, recent results suggested that statins could modulate the expression levels of Cxs and subsequently the functions of gap junctions [21]. Furthermore, the activities of statins on Cxs and gap junctions were proved to be closely related to their pharmacological effects against atherosclerosis, neointimal hyperplasia, arrhythmia, as well as cancer. In the present review, we will summarize the pharmacological effects of statins related to gap junction modulation based on available results in literatures.

\section{Anti-Atherosclerotic and Anti-Proliferative Effects of Statins Are Related to Modulation of Cxs and Gap Junctions}

Cxs 37, 40, and 43 are the main kinds of gap junction proteins detected in arterial walls, and they are implicated in the progression of atherosclerosis [21] [13] [22]. Endothelium and smooth muscle cells (SMCs) in the arteries have different patterns of Cx expression [12] [13]. Cx37 is predominantly expressed in endothelial cells [23]. It was reported that impaired Cx37 expression could be linked to endothelial dysfunction and the development of atherosclerosis [12] [13]. On the contrary, proper expression of Cx37 in macrophages could inhibit cell adhesion and the formation of atherosclerotic plaque [24]. Cx40 could be detected both in endothelium and in SMCs [23] [25]. It seemed that endothelial Cx40 played a role similar to that of Cx37, as deletion of Cx40 in endothelium could accelerate atherosclerosis [26]. Cx40 in SMCs may play a different role. There were reports that Cx40 could be up-regulated in SMCs of rabbit arteries either with atherosclerotic lesions [25] or subjected to balloon injury [27].

Cx43 is mainly expressed in SMCs [23] [25] [27] and could be detected in some endothelial cells [28]. Cx43 in arterial SMCs plays an important role in the development atherosclerosis [12] [22] [25] [27] [29]. In $L^{2} L^{-/-}$ mice fed with cholesterol-rich diet, the development of aortic atherosclerotic lesions could be reduced greatly 
<smiles>CCC(C)(C)C(=O)O[C@H]1CC(C)C=C2C=CC(C)[C@H](CC[C@@H]3C[C@@H](O)CC(=O)O3)[C@H]21</smiles>

Molecular Weight: 404.54

Lovastatin<smiles>CC(C)N1c2ccccc2C(c2ccc(F)cc2)C1/C=C/[C@H](O)CC(O)CC(=O)[O-]</smiles>

Molecular Weight: 412.47

Fluvastatin<smiles>CCC(C)(C)C(=O)O[C@H]1C[C@@H](C)C=C2C=CC(C)[C@H](CCC3C[C@H](O)CC(=O)O3)[C@]21C</smiles>

Molecular Weight: 418.57

Simvastatin<smiles>CC(C)c1c(C(=O)Nc2ccccc2)c(-c2ccccc2)c(-c2ccc(F)cc2)n1CC[C@H](O)C[C@@H](O)CC(=O)[O-]</smiles>

Molecular Weight: 557.63

Atorvastatin<smiles>CCC(C)(C)C(=O)O[C@H]1CC(O)C=C2C=CC(C)C(CC[C@H](O)CC(O)CC(=O)[O-])[C@]21C</smiles>

Molecular Weight: 437.55

Pravastatin<smiles>COCc1c(C(C)C)nc(C(C)C)c(/C=C/C(O)C[C@H](O)CC(=O)[O-])c1-c1ccc(F)cc1</smiles>

Molecular Weight: 458.54

\section{Cerivastatin}<smiles>O=C([O-])C[C@H](O)C[C@@H](O)C=Cc1c(-c2ccc(F)cc2)nc2ccccc2c1C1CC1</smiles>

Molecular Weight: 420.45<smiles>CC(C)c1nc(N(C)S(C)(=O)=O)nc(-c2ccc(F)cc2)c1/C=C/[C@H](O)C[C@@H](O)CC(=O)[O-]</smiles>

Molecular Weight: 480.53

Pitavastatin

Rosuvastatin

\section{Figure 1. Chemical structures of statins.}

through Cx43 knockdown [29]. Increased expression of Cx43 was related to the transformation of SMCs to synthetic phenotype, which could contribute to the production of extracellular matrix and development of lesions [30] [31]. Over-expression of Cx43 was also observed in the migration and proliferation of SMCs [22]. Now, Cx43 is considered as a potential useful target to inhibit atherogenesis [25] [29].

Besides cholesterol-lowering and anti-inflammatory effects, modulation of Cxs and gap junctions may also contribute to the anti-atherosclerotic activities of statins [25] [29] [32]. Effects of different statins on the expressions of Cxs and functions of gap junctions in SMCs and endothelial cells related to atherosclerosis or neointimal hyperplasia are summarized in Table 1 (Part 1). 
Table 1. Effects of statins on Cxs and gap junctions related to cardiovascular disorders and cancer.

\begin{tabular}{|c|c|c|c|c|}
\hline \multirow{2}{*}{ References } & \multirow{2}{*}{$\begin{array}{l}\text { Animal models or } \\
\text { cell types }\end{array}$} & \multirow{2}{*}{ Statins studied } & \multicolumn{2}{|l|}{ Effects of statins } \\
\hline & & & Cx expression and gap junction & Improvement of pathological changes \\
\hline \multicolumn{5}{|c|}{ Part 1: Modulation of Cxs/gap junctions by statins against atherosclerosis and neointimal hyperplasia } \\
\hline [25] & $\begin{array}{l}\text { rabbits fed with } \\
\text { high-cholesterol diet }\end{array}$ & $\begin{array}{l}\text { lovastatin, } \\
\text { fluvastatin }\end{array}$ & $\begin{array}{l}\text { expressions of } \mathrm{Cx} 43 \text { and } \mathrm{Cx} 40 \text { in } \\
\text { lesions reduced, volume and size of } \\
\text { gap junctions between SMCs reduced }\end{array}$ & $\begin{array}{l}\text { neointima decreased in atherosclerotic } \\
\text { lesions }\end{array}$ \\
\hline \multirow{2}{*}{ [29] } & $\begin{array}{l}L D L R^{-/} \text {mice fed } \\
\text { with cholesterol-rich } \\
\text { diet }\end{array}$ & pravastatin & Cx43 expression reduced in lesions & $\begin{array}{l}\text { improvement of plaque morphology and } \\
\text { stability }\end{array}$ \\
\hline & $\begin{array}{l}\text { cultured SMCs } \\
\text { isolated from human } \\
\text { saphenous veins }\end{array}$ & simvastatin & $\begin{array}{l}\text { Cx43 expression reduced, reduced } \\
\text { transfer of gap junction-permeable dye }\end{array}$ & ND \\
\hline \multirow[b]{2}{*}{ [32] } & $\begin{array}{l}\text { rabbits fed with } \\
\text { high-cholesterol diet }\end{array}$ & $\begin{array}{l}\text { vytorin } \\
\text { (simvastatin/ } \\
\text { ezetimebe) }\end{array}$ & $\begin{array}{l}\text { Cx43 expression reduced in aortic } \\
\text { walls }\end{array}$ & $\begin{array}{l}\text { neointimal hyperplasia and inflammatory } \\
\text { cell infiltration reduced in lesions }\end{array}$ \\
\hline & $\begin{array}{l}\text { cultured rat aortic } \\
\text { SMCs, stimulated } \\
\text { with or without } \\
\text { TNF- } \alpha / \text { IL-18 }\end{array}$ & simvastatin & $\begin{array}{l}\text { Cx43 expression reduced } \\
\text { (constitutive level as well as increased } \\
\text { expression induced by TNF- } \alpha / \text { IL-18) }\end{array}$ & over-proliferation of SMCs suppressed \\
\hline [27] & $\begin{array}{l}\text { rabbits, arteries } \\
\text { subjected to balloon } \\
\text { injury }\end{array}$ & $\begin{array}{l}\text { lovastatin, } \\
\text { fluvastatin }\end{array}$ & $\begin{array}{l}\text { expressions of } \mathrm{Cx} 43 \text { and } \mathrm{Cx} 40 \\
\text { reduced in neointimal SMCs, volume } \\
\text { and size of gap junctions reduced }\end{array}$ & neointima decreased \\
\hline [33] & $\begin{array}{l}\text { ex vivo cultured } \\
\text { human saphenous } \\
\text { veins }\end{array}$ & fluvastatin & $\begin{array}{l}\text { expression of } \mathrm{Cx} 43 \text { reduced in } \\
\text { neointimal SMCs }\end{array}$ & neointima decreased \\
\hline [34] & $\begin{array}{l}\text { cultured rat aortic } \\
\text { SMCs }\end{array}$ & lovastatin & GJIC inhibited between SMCs & migration of SMCs inhibited \\
\hline [35] & $\begin{array}{l}\text { cultured SMCs } \\
\text { isolated from human } \\
\text { saphenous veins }\end{array}$ & $\begin{array}{l}\text { atorvastatin } \\
\text { controlled release } \\
\text { from hydrogel }\end{array}$ & expression of $\mathrm{Cx} 43$ reduced & $\begin{array}{l}\text { proliferation and migration of SMCs } \\
\text { inhibited }\end{array}$ \\
\hline [37] & $\begin{array}{l}\text { rat diabetes induced } \\
\text { by STZ injection }\end{array}$ & simvastatin & $\begin{array}{l}\text { reversed the down-regulation of } \mathrm{Cx} 43 \\
\text { in aortic walls of diabetic mice }\end{array}$ & ND \\
\hline [39] & hereditary HTG rats & atorvastatin & $\begin{array}{l}\text { Cx43 expression reduced in aorta, } \\
\text { distribution of Cx43 modified between } \\
\text { endothelium and media }\end{array}$ & integrity of endothelium improved \\
\hline [40] & cultured HUVEC & $\begin{array}{l}\text { fluvastatin, } \\
\text { lovastatin, } \\
\text { pravastatin, } \\
\text { simvastatin }\end{array}$ & $\begin{array}{l}\text { statins reduced Cx } 43 \text { expression when } \\
\text { treated alone, but could reverse the } \\
\text { down-regulating effect of nicotine on } \\
\text { Cx43 }\end{array}$ & ND \\
\hline$[41]$ & $\begin{array}{l}\text { mice hyperlipidemia } \\
\text { induced by } \\
\text { cholesterol-rich diet }\end{array}$ & simvastatin & $\begin{array}{l}\text { reversed the reduction of Cx37 and gap } \\
\text { junctions in aortic endothelium }\end{array}$ & ND \\
\hline$[42]$ & $\begin{array}{l}\text { STZ induced } \\
\text { diabetes in } \\
\text { ApoE-deficient mice }\end{array}$ & simvastatin & $\begin{array}{l}\text { exacerbated the reduction of Cx37 and } \\
\text { Cx40 in aortic endothelium }\end{array}$ & - \\
\hline \multicolumn{5}{|c|}{ Part 2: Modulation of Cxs/gap junctions by statins against arrhythmia and myocardial injury/hypertrophy } \\
\hline [48] & hereditary HTG rats & atorvastatin & $\begin{array}{l}\text { Cx43 expression increased, } \\
\text { phosphorylation normalized; gap } \\
\text { junction remodeling suppressed, } \\
\text { integrity improved in ventricles }\end{array}$ & $\begin{array}{l}\text { threshold for electric-induced VF } \\
\text { increased }\end{array}$ \\
\hline [49] & $\begin{array}{l}\text { rat acute MI induced } \\
\text { by coronary artery } \\
\text { ligation }\end{array}$ & pravastatin & $\begin{array}{l}\text { Cx43 expression increased, gap } \\
\text { junction remodeling suppressed }\end{array}$ & incidence of VT/VF decreased \\
\hline$[50][51]$ & $\begin{array}{l}\text { mice viral myocarditis } \\
\text { induced by CVB3 }\end{array}$ & $\begin{array}{l}\text { atorvastatin, } \\
\text { pravastatin }\end{array}$ & $\begin{array}{l}\text { restored the reduction of } \mathrm{Cx} 43 \text { and } \\
\text { Cx45 in hearts, suppressed gap } \\
\text { junction remodeling }\end{array}$ & $\begin{array}{l}\text { myocardial inflammatory cell } \\
\text { infiltration and necrosis decreased, } \\
\text { animal survival rate increased }\end{array}$ \\
\hline
\end{tabular}


Continued

\begin{tabular}{|c|c|c|c|c|}
\hline [52] & $\begin{array}{l}\text { rat diabetes induced } \\
\text { by STZ injection }\end{array}$ & simvastatin & $\begin{array}{l}\text { restored Cx43 expression and integrity } \\
\text { of gap junctions in hearts }\end{array}$ & apoptosis of cardiomyocytes decreased \\
\hline [56] & $\begin{array}{l}\text { LV hypertrophy in } \\
\text { SHR }\end{array}$ & atorvastatin & $\begin{array}{l}\text { Cx43 expression reduced, gap junction } \\
\text { remodeling suppressed in LV }\end{array}$ & LV hypertrophy ameliorated \\
\hline [57] & $\begin{array}{l}\text { LV hypertrophy } \\
\text { induced by } \\
\text { abdominal aortic } \\
\text { constriction in rats }\end{array}$ & atorvastatin & $\begin{array}{l}\text { gap junction (Cx43) remodeling } \\
\text { suppressed }\end{array}$ & LV hypertrophy ameliorated \\
\hline [58] & $\begin{array}{l}\text { Ang II induced } \\
\text { hypertrophy jn } \\
\text { primarily cultured rat } \\
\text { atrial myocytes }\end{array}$ & atorvastatin & $\begin{array}{l}\text { expression of Cx40 increased, gap } \\
\text { junction remodeling suppressed }\end{array}$ & $\begin{array}{l}\text { hypertrophy of atrial myocytes } \\
\text { ameliorated }\end{array}$ \\
\hline \multicolumn{5}{|c|}{ Part 3: Modulation of Cxs/gap junctions by statins against tumors } \\
\hline \multirow[b]{2}{*}[66]{} & $\begin{array}{l}\text { ras-transformed rat } \\
\text { liver epithelial cells }\end{array}$ & lovastatin & GJIC enhanced & $\begin{array}{l}\text { transformation and tumorigenesis of the } \\
\text { cells inhibited }\end{array}$ \\
\hline & $\begin{array}{l}\text { rat hepatic tumors } \\
\text { induced by } \\
\text { ras-transformed liver } \\
\text { epithelial cells }\end{array}$ & lovastatin & ND & tumor size decreased \\
\hline$[67][68]$ & $\begin{array}{l}\text { MCF-7 breast cancer } \\
\text { cells }\end{array}$ & lovastatin & GJIC enhanced & $\begin{array}{l}\text { proliferation inhibited, cell cycle } \\
\text { arrested, differentiation induced }\end{array}$ \\
\hline \multirow[t]{2}{*}{ [69] } & $\begin{array}{l}\text { adenocarcinoma cell } \\
\text { mixture containing } \\
\text { WT (90\%) and } \\
\text { HSV-tk transduced } \\
(10 \%) \text { cells }\end{array}$ & lovastatin & GJIC enhanced & $\begin{array}{l}\text { BSE enhanced and tumor cell killing } \\
\text { increased when co-administered with } \\
\text { GCV }\end{array}$ \\
\hline & $\begin{array}{l}\text { mice subcutaneous } \\
\text { tumors induced by } \\
\text { adenocarcinoma cell } \\
\text { mixture }\end{array}$ & lovastatin & ND & $\begin{array}{l}\text { tumor-free survival rate of the mice } \\
\text { increased when co-administered with } \\
\text { GCV }\end{array}$ \\
\hline [70] & MLTC-1 & simvastatin & $\begin{array}{l}\text { Cx43 expression had no change but } \\
\text { phosphorylation decreased and } \\
\text { membrane localization increased, } \\
\text { GJIC enhanced }\end{array}$ & cytotoxicity of etoposide increased \\
\hline
\end{tabular}

Abbreviations: Cxs: connexins, LDLR: low-density lipoprotein receptor, SMC: smooth muscle cell, ND: not determined, TNF- $\alpha$ : tumor necrosis factor- $\alpha$, IL-18: interleukin-18, GJIC: gap junctional intercellular communication, HTG: hypertriglyceridemic, HUVEC: human umbilical vein endothelial cells, STZ: streptozotocin, MI: myocardial infarction, -: no effect, VT: ventricular tachycardia, VF: ventricular fibrillation, CBV3: coxsackievirus B3, LV: left ventricular, SHR: spontaneously hypertensive rats, Ang: angiotensin, WT: wild-type, HSV-tk: herpes simplex virus thymidine kinase, BSE: bystander effect, GCV: ganciclovir, MLTC: murine Leydig tumor cells.

In aortic lesions of animal atherosclerosis induced by high-cholesterol diet, the over-expressions Cx43 and Cx40 could be suppressed by statins [25] [29] [32]. The inhibitory effect of statins on Cx43/Cx40 was observed in SMCs and was associated with the reduction of volume and size of gap junctions between SMCs [25] [29] [32]. These findings indicated that enhanced intercellular communications between SMCs, which could induce migration, proliferation and transformation, may be released by statins. Indeed, the inhibitory effect of statins on aortic $\mathrm{Cx} 43 / \mathrm{Cx} 40$ was accompanied by the reduction of neointimal hyperplasia in lesions and the improvement of plaque morphology and stability [25] [29] [32].

Besides diet induced vessel disorder, the inhibitory effect of statins on Cx43/Cx40 could be observed in arteries subjected to mechanical damage, as well [27]. In rabbit arteries subjected to balloon injury, statins could reduce the expression levels of $\mathrm{Cx} 43$ and $\mathrm{Cx} 40$ in SMCs, which was correlated to the decrease of neointimal hyperplasia [27]. In addition to arteries, the anti-proliferative effects of statins could also be found in veins. In ex vivo cultured human saphenous veins, statin treatment suppressed the expression of $\mathrm{Cx} 43$ in neointimal SMCs and then inhibited neointimal hyperplasia [33].

The detailed mechanisms as well as cellular signaling pathways recruited by statins to inhibit $\mathrm{Cx} 43 / \mathrm{Cx} 40 \mathrm{ex}-$ pression and gap junctional communication in SMCs are not fully elucidated. Some mechanism studies had been conducted in cuntured SMCs [29] [32] [34] [35]. Statin treatment inhibited the expression of Cx43 in SMCs and 
suppressed gap junctional intercellular communication (GJIC) accordingly [29] [32] [34] [35]. As a result, the proliferation and migration of SMCs could be inhibited by statins [29] [32] [34] [35]. As gap junctions could be up-regulated by increase of cellular cholesterol level [36], it was postulated that statins may suppress Cx43 expression through inhibiting cholesterol biosynthesis (Figure 2). Indeed, in SMCs, the inhibitory effect of statins on Cx43 could be abolished by supplement of mevalonate [29].

The inhibitory effect of statins on Cx43 was also associated with suppression of proinflammatory cytokines (Figure 2) and relevant cellular signaling pathways [32]. In cultured aortic SMCs, simvastatin could attenuate the up-regulating effects of tumor necrosis factor- $\alpha$ (TNF- $\alpha$ ) and interleukin-18 (IL-18) on Cx43 [32]. Furthermore, the inhibitory effects of simvastatin was associated with blockade of phosphatidylinositol 3-kinase (PI3K)/Akt and mitogen-activated protein kinase (MAPK) pathways, which could be elicited by TNF- $\alpha$ and IL-18 [32].

It should be mentioned that the expressional regulations of Cxs are complex, which may include transcriptional as well as post-transcriptional events [8]-[10]. Whether or not statins have influences on these processes is unknown and needs investigation.

Although the majority of reports supported that atherogenic factors could increase the expression of Cx43 in SMCs, converse results existed. For example, a report suggested that the expression of Cx43 in aortic SMCs was reduced in the background of diabetes mellitus in rats [37]. And surprisingly, simvastatin was shown to reverse the reduction [37]. The explanation for the discrepancies is unclear, and the relevance of this observation to the progression of atherosclerosis needs to be clarified.

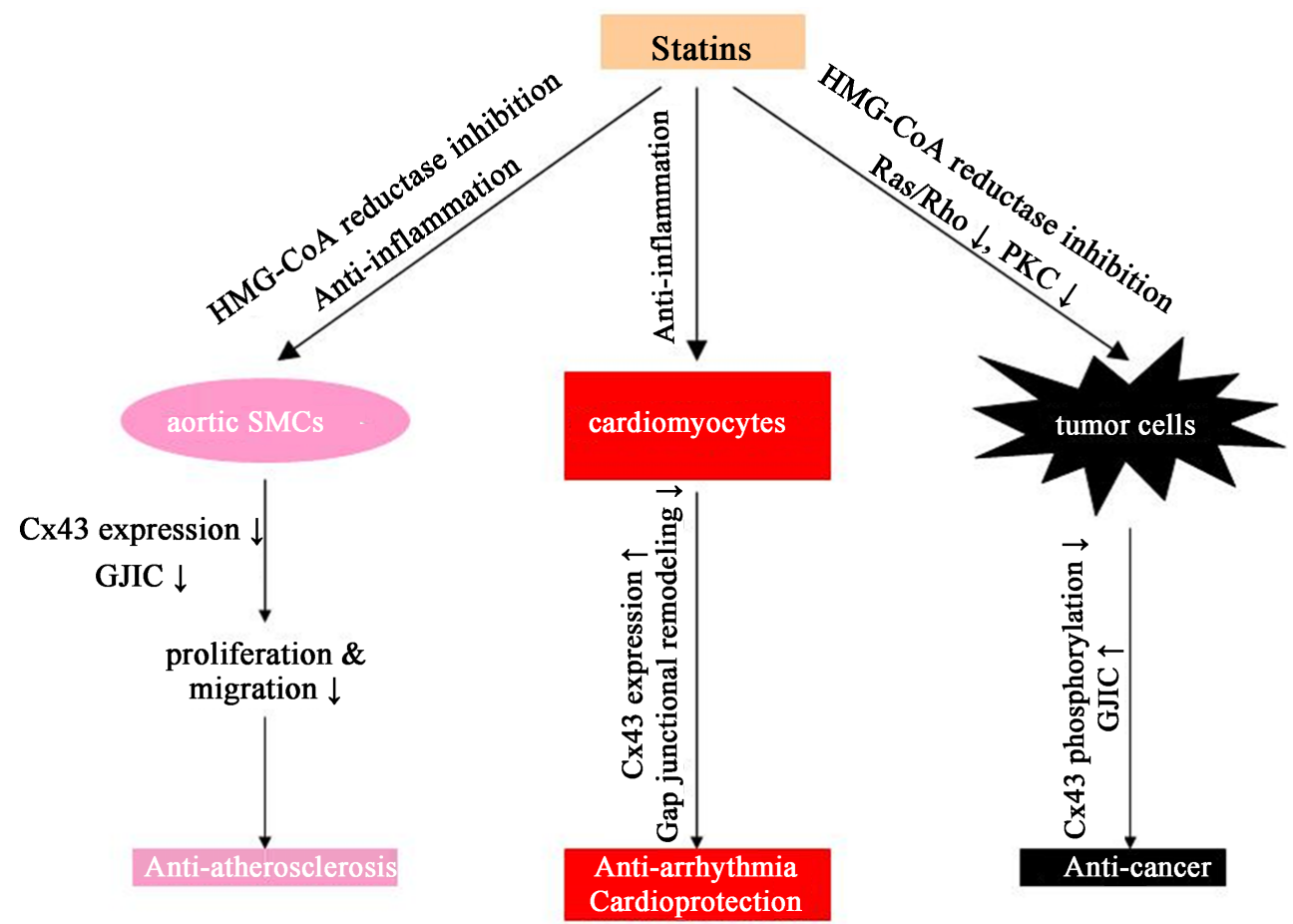

Figure 2. Supposed mechanisms of statins in modulating Cx43 and gap junctions against cardiovascular disorders and tumors. (1) In aortic SMCs, statins could suppress Cx43 expression and GJIC, probably through HMG-CoA reductase inhibition and anti-inflammation. The effects of statins on gap junctions were associated with suppression of SMCs and subsequently the development of atherosclerosis. (2) In cardiomyocytes, statins could increase Cx43 expression and inhibit gap junction remodeling, probably through anti-inflammation. The effects of statins on gap junctions were associated with suppression of arrhythmia as well as cardiac injury. (3) In some tumor cells, statins could reduce Cx43 phosphorylation and enhance GJIC, probably through HMG-CoA reductase inhibition and subsequent suppression of Ras/Rho as well as PKC. The effects of statins on gap junctions were associated with their anti-cancer activities. Abbreviations: HMG-CoA: 3-hydroxy-3-methylglutaryl coenzyme A, SMCs: smooth muscle cells, Cx: connexin, GJIC: gap junctional intercellular communication, PKC: protein kinase C. 
Endothelial dysfunctions are also pivotal to the development of atherosclerosis. Atherogenic factors generally down-regulate the expressions of Cxs in endothelial cells [38], which could be modified by statins (Table 1, Part 1). In hereditary hypertriglyceridemic (HTG) rats [39], the expression of Cx43 was increased in aortic media which contain SMCs but decreased in aortic endothelial cells as compared with those of wild type rats. Administration of atorvastatin reduced total aortic $\mathrm{Cx} 43$ expression and modified the distribution of $\mathrm{Cx} 43$ between endothelium and media. In detail, atorvastatin could increase endothelial Cx43 expression and reduce media Cx43 expression markedly in aortic walls of hereditary HTG rats. The recovery of Cx43 expression in endothelium by atorvastatin was connected with the improvement of endothelial integrity [39].

The effects of statins on endothelial Cx43 were also observed in vitro in cultured human umbilical vein endothelial cells (HUVEC) [40]. Statins alone reduced the expression of Cx43 in HUVEC, which may attribute to the inhibition of endogenous cholesterol biosynthesis [29] [36]. However, when co-administered with nicotine, an atherogenic factor which down-regulates $\mathrm{Cx} 43$ expression and GJIC in endothelial cells, statins could reverse its effects [40]. The mechanism of statins in increasing endothelial Cx43 expression is unclear and needs investigation.

Cx37 and Cx40 are the predominantly expressed Cxs in aortic endothelial cells [23], and their expressions could be regulated by statins. In hyperlipidemic mice fed with cholesterol-rich diet [41], simvastatin could reverse the reduction of Cx37 and gap junctions in aortic endothelial cells. There were conflicting results concerning the effects of statins on endothelial Cx37 expression. For example, in diabetic ApoE-deficient mice [42], simvastatin was reported to further reduce the impaired Cx37/Cx40 expressions in aortic endothelial cells. The discrepancies were supposed to be related to altered pharmacokinetics and actions of statins due to different animal models or genetic backgrounds [42]. However, the detailed mechanism of statins in regulating endothelial Cx37 and the relevance to atherosclerosis remain to be clarified.

In summary (Table 1, Part 1), statins could modulate the expressions of Cxs 37, 40, and 43 and functions of gap junctions in aortic walls; the effects of statins were variable depending on different cell types; and the modulation of statins on aortic Cxs and gap junctions was correlated to their beneficial effects against athrosclerosis as well as neointimal hyperplasia [25] [27] [29] [32]-[35] [37] [39]-[42].

\section{Antiarrhythmic and Cardioprotective Effects of Statins Are Related to Modulation of Cxs and Gap Junctions}

Cxs 37, 40, 43 and 45 are the major gap junction proteins expressed in the heart [43] [44]. Cxs 37 and 43 could be detected in ventricle as well as atrium of human hearts; Cx40 is mainly expressed in atrium; while Cx45 is highly expressed in sinoatrial node [43] [44]. Appropriate cell-to-cell communication mediated by these gap junction proteins is of extreme importance in maintaining proper electrical coupling and synchronization of cardiomyocytes [16] [45]. Impairment of GJIC due to alterations of expression, distribution, or phosphorylation of Cxs could lead to myocardial dysfunction and severe arrhythmia which could increase mortality [16] [45] [46]. Statins were reported to have antiarrhythmic effects independent of their cholesterol-lowering activity [47]. Although the detailed mechanisms remain elusive, evidences suggested that the antiarrhythmic effects of statins could be related to modulation of Cxs and gap junctions in cardiomyocytes [48] [49].

Effects of different statins on myocardial Cxs/gap junctions against arrhythmia and cardiac injury/hypertrophy are summarized in Table 1 (Part 2). It was obvious that cardiac risk factors such as hyperlipidemia, stenosis, viral infection, and diabetes could disturb the proper expression, distribution, phosphorylation and integrity of Cxs/gap junctions in cardiomyocytes [48]-[52]. Furthermore, the alterations of Cxs/gap junctions were associated with cardiac abnormalities such as arrhythmia, necrosis and apoptosis of cardiomyocytes in animals [48]-[52]. Intervention with statins could restore myocardial Cxs and GJIC [48]-[52]. In detail, statins could increase the myocardial expressions of $\mathrm{Cx} 43$ and $\mathrm{Cx} 45$, which were down-regulated in animals with hypertriglyceridemia, acute myocardial infarction (MI), viral myocarditis, or diabetes [48]-[52]. Besides, statins could restore the disordered distribution and suppress remodeling of gap junctions [48]-[52]. In normal cardiomyocytes, gap junctions are mainly distributed in the intercalated disc region; but in abnormal cardiomyocytes, the distribution of gap junctions are usually disordered and scattered [45] [46]. Remodeling of gap junctions is closely related to the development of arrhythmia [45] [46].

The beneficial effect of statins on gap junctions was also indicated by modulation of phosphorylation of Cxs 
[48], which may be related to their internalization and degradation [53]. In hereditary HTG rats [48], Cx43 was found to be hyperphosphorylated in the heart; atorvastatin could normalize it and help to improve the integrity of gap junctions. In animal models mentioned above, restoration of myocardial Cxs and gap junctions was associated with the pharmacological effects of statins against arrhythmias and cardiac dysfunctions [48]-[52]. Lethal arrhythmias like ventricular tachycardia (VT) and ventricular fibrillation (VF) could be blocked by statins in rats with acute MI [49]. In addition, statin administration could protect cardiomyocytes from necrosis and apoptosis induced by viral infection or diabetes and thus improve the survival rate of animals [50]-[52].

The mechanisms underlying the restoring effect of statins on myocardial gap junctions are far from elucidation. However, available results suggested that anti-inflammatory effects of statins may be involved (Figure 2) [49]-[52]. For example, in mice viral myocarditis induced by coxsackievirus B3 (CVB3), the restoration of Cxs and gap junctions was accompanied by reduction of proinflammatory cytokines such as TNF- $\alpha$ and interferon- $\gamma$ (IFN $\gamma$ ) in the heart after statin therapy [50] [51]. These cytokines were associated with impaired Cx43 expression and gap junction remodeling in the heart [54]. These findings indicate that the anti-inflammatory and immunomodulatory effects of statins may contribute in part to the improvement of gap junctional communication between cardiomyocytes.

Besides arrhythmia and myocarditis, statins could modulate Cxs/gap junctions in cardiac hypertrophy, as well (Table 1, Part 2). Abnormalities of Cxs/gap junctions may take part in the progression of cardiac hypertrophy, for example, induced by hypertension [55]. However, concerning the expressions of Cxs in hypertrophied cardiomyocytes, conflicting results exist. For example, in hypertrophied left ventricle (LV) of spontaneously hypertensive rats (SHR), the expression of $\mathrm{Cx} 43$ was shown to be increased as compared to that of wild type rats [56]. But in rats subjected to abdominal aortic constriction, the expression of $\mathrm{Cx} 43$ seemed to be unchanged in hypertrophied LV [57]. These discrepancies could be due to the use of different models or different stages of cardiac hypertrophy. However, interestingly, no matter how Cx43 is expressed, gap junction remodeling occurs in hypertrophied cardiomyocytes, indicating its important role in the development of cardiac hypertrophy [56] [57]. Accordingly, administration of atorvastatin suppressed gap junction remodeling in LV of SHR and rats subjected to abdominal aortic constriction [56] [57]. The beneficial effect of atorvastatin on myocardial gap junction was associated with amelioration of LV hypertrophy in these animal models [56] [57].

In addition, in angiotensin (Ang) II treated and hypertrophied primarily cultured rat atrial myocytes, atorvastatin could up-regulate the expression of Cx40 and suppress gap junction remodeling [58]. As Cx40 is predominantly expressed in atrium [43] and is close related to the development of atrial arrhythmias like atrial fibrillation (AF) [59], the restoring effect of statins on it may contribute to the improvement of AF in clinic [60].

In summary (Table 1, Part 2), statins could modulate the expressions of Cxs 40, 43, and 45, and suppress gap junction remodeling in cardiomyocytes; the restoring effects of statins on myocardial Cxs and gap junctions were correlated to their beneficial effects against arrhythmias and myocardial injury/hypertrophy induced by a variety of risk factors [48]-[52], [56]-[58].

\section{Anti-Neoplastic Effects of Statins Are Related to Modulation of Cxs and Gap Junctions}

Numerous results, both in laboratory as well as in clinic, proved that statins had anti-neoplastic activities against a variety of tumors [61]. The use of statins was probably associated with reduced risks of some cancers in clinic, such as hepatocellular cancer and prostate cancer [62] [63]. And notably, a recent survey indicated that the use of statins may result in the reduction of cancer-specific mortality with clinical significance [64]. Statins could inhibit the proliferation and metastasis of cancer cells when treated alone. And when combined with other anti-cancer agents, they may have sensitizing effects [61]. Multiple mechanisms have been suggested in order to explain the anti-neoplastic effects of statins. For example, statins could suppress the post-translational modification of the Ras/Rho superfamily of GTPases through inhibition of HMG-CoA reductase [65]. As a result, the membrane association of Ras/Rho GTPases could be blocked, and subsequently, downstream tumorigenic signaling molecules could be reduced [65]. Among various mechanisms and pathways, it is worth to mention that modulation of Cxs and gap junctions may contribute in part to the anti-cancer activities of statins (Table 1, Part 3) [66]-[70].

In the development of cancer, disruption of gap junctions and related cell-to-cell communications is a very important factor for the transformation and malignant change of cells [71]. Now, Cxs and gap junctions are con- 
sidered as potential useful targets for the treatment of cancer, as proliferation of cancer cells could be inhibited effectively through restoration of gap junctions [71].

An early study indicated that lovastatin could enhance GJIC in ras-transformed rat liver epithelial cells, which was accompanied by the suppression of transformation and tumorigenesis of the cells [66]. In MCF-7 breast cancer cells, lovastatin could enhance GJIC, as well [67] [68]. And the restoration of GJIC was associated with the proliferation inhibiting, cell cycle arresting, as well as differentiation inducing efficacies of lovastatin [67] [68].

In addition to direct anti-neoplastic actions, modulation of Cxs/gap junctions may also contribute to the sensitizing effects of statins on other anti-cancer agents, which is mainly mediated by the bystander effect (BSE) [69] [70]. BSE in tumors is mainly induced by gap junctional transfer of anti-cancer materials between adjacent cells [69] [70]. In an early study [69], lovastatin was shown to enhance the BSE in a herpes simplex virus thymidine kinase/ganciclovir (HSV-tk/GCV) gene therapy system against adenocarcinoma cells. In that system, lovastatin could enhance cellular GJIC and then increase the gap junctional transfer of phosphorylated GCV. As a result, the anti-cancer activity of GCV could be increased by co-administration of lovastatin, both in vitro and in vivo [69]. In a recent study [70], simvastatin was shown to increase the cytotoxicity of etoposide against murine Leydig tumor cells (MLTC-1) via GJIC restoration, which may facilitate the transfer of toxic molecules between cells (BSE).

How GJIC could be modulated by statins in tumor cells is not fully elucidated. However, some results suggested that statins could regulate the phosphorylation of $\mathrm{Cx} 43$, which may play a role in its internalization and degradation [53]. For example, in MLTC-1, simvastatin administration had no effect on Cx43 expression, but could obviously inhibit its phosphorylation at ser368 [70]. The membrane localization of Cx43 was then enhanced, resulting in increase of GJIC (Figure 2) [70].

Simvastatin decreased Cx43 phosphorylation in MLTC-1 through inhibiting protein kinase C (PKC) [70], which was shown to phosphorylate Cx43 and impair GJIC [72]. The expression level and activity of PKC was proved to be down-regulated by simvastatin in MLTC-1 [70]. Upstream events resulting in PKC inhibition may include suppression of Ras/Rho GTPases (Figure 2), as the oncogenic Ras was shown to block GJIC in cancer cells through a PKC-dependent mechanism, which could be reversed by statins [66] [73].

In summary (Table 1, Part 3), statins could enhance GJIC in some tumor types, which may contribute in part to their anti-cancer activities, either treated alone or in combination with other agents [66]-[70].

\section{Prospects of Statins on Gap Junctions}

The modulating effects of statins on cellular Cxs and gap junctions are of potential importance, as they may provide a possible explanation and an internal connection for the pleiotropic pharmacological effects of statins, considering the broad expressions of Cxs in various tissues [5] [8]. It seems that the expressions of Cxs and functions of gap junctions could be disturbed by pathological factors in various tissues, either enhanced or attenuated. Importantly, statins could rectify the abnormalities of gap junctions and thus the pathological changes of corresponding tissues (Figure 2). The detailed mechanisms underlying the effects of statins on Cxs and gap junctions are not clear and need further investigation. For example, the anti-inflammatory effects of statins could confer to differential modulations of Cx43 in aortic SMCs and cardiomyocytes (Figure 2) [32] [50] [51]. The explanation is not available and need further study. And for the effects of statins on gap junctions against cancer, it seems that available data of relevance are limited. Future studies should expand the research field in tumor types, and the clinical significance of statin-mediated gap junction modulation in cancer treatment should be investigated.

In addition to the diseases and disorders mentioned in this text, statins have beneficial effects against some other diseases of major clinical importance, such as diabetic complications and osteoporosis [19] [20] [74] [75]. The development of osteoporosis and diabetic complications such as nephropathy and retinopathy was proved to be closely related to the dysfunction of cellular gap junctions [14] [15] [76]. Considering the encouraging results that rosuvastatin could restore $\mathrm{Cx} 43$ in the kidney of SHR which was correlated to the improvement of glomerular ultrastructure [21], it is rational to infer that the pharmacological activities of statins against some of the microvascular complications of diabetes may be attributable, at least in part, to the modulation of gap junctions. Future laboratory as well as clinical studies are warranted to support these assumptions. Clarification of these issues will help to provide scientific evidences for the appropriate clinical application of statins. 


\section{Conclusion}

Some of the pharmacological effects of statins against cardiovascular disorders or tumors were proved to be related to the modulation of cellular Cxs and gap junctions (Figure 2). However, detailed mechanisms, which may involve the anti-inflammatory or HMG-CoA reductase inhibiting effects of statins, still need further investigation.

\section{Acknowledgements}

This work was supported by the National Mega-Project for Innovative Drugs (2012ZX09301-002-001-015).

\section{Conflict of Interests}

The authors have no conflict of interests in this paper.

\section{References}

[1] Brooke, M.A., Nitoiu, D. and Kelsell, D.P. (2012) Cell-Cell Connectivity: Desmosomes and Disease. The Journal of Pathology, 226, 158-171. http://dx.doi.org/10.1002/path.3027

[2] Nekrasova, O. and Green, K.J. (2013) Desmosome Assembly and Dynamics. Trends in Cell Biology, 23, 537-546. http://dx.doi.org/10.1016/j.tcb.2013.06.004

[3] Roberts, T.K., Eugenin, E.A., Lopez, L., Romero, I.A., Weksler, B.B., Couraud, P.O. and Berman, J.W. (2012) CCL2 Disrupts the Adherens Junction: Implications for Neuroinflammation. Laboratory Investigation, 92, 1213-1233. http://dx.doi.org/10.1038/labinvest.2012.80

[4] Rodgers, L.S., Beam, M.T., Anderson, J.M. and Fanning, A.S. (2013) Epithelial Barrier Assembly Requires Coordinated Activity of Multiple Domains of the Tight Junction Protein ZO-1. Journal of Cell Science, 126, 1565-1575. http://dx.doi.org/10.1242/jcs.113399

[5] Meșe, G., Richard, G. and White, T.W. (2007) Gap Junctions: Basic Structure and Function. Journal of Investigative Dermatology, 127, 2516-2524. http://dx.doi.org/10.1038/sj.jid.5700770

[6] Wang, X., Veruki, M.L., Bukoreshtliev, N.V., Hartveit, E. and Gerdes, H.H. (2010) Animal Cells Connected by Nanotubes Can Be Electrically Coupled through Interposed Gap-Junction Channels. Proceedings of the National Academy of Sciences of the United States of America, 107, 17194-17199. http://dx.doi.org/10.1073/pnas.1006785107

[7] Revel, J.P. and Karnovsky, M.J. (1967) Hexagonal Array of Subunits in Intercellular Junctions of the Mouse Heart and Liver. The Journal of Cell Biology, 33, C7-C12. http://dx.doi.org/10.1083/jcb.33.3.C7

[8] Laird, D.W. (2010) The Gap Junction Proteome and Its Relationship to Disease. Trends in Cell Biology, 20, 92-101. http://dx.doi.org/10.1016/j.tcb.2009.11.001

[9] Bosco, D., Haefliger, J.A. and Meda, P. (2011) Connexins: Key Mediators of Endocrine Function. Physiological Reviews, 91, 1393-1445. http://dx.doi.org/10.1152/physrev.00027.2010

[10] Laird, D.W. (2006) Life Cycle of Connexins in Health and Disease. Biochemical Journal, 394, 527-543. http://dx.doi.org/10.1042/BJ20051922

[11] Potolicchio, I., Cigliola, V., Velazquez-Garcia, S., Klee, P., Valjevac, A., Kapic, D., Cosovic, E., Lepara, O., Hadzovic-Dzuvo, A., Mornjacovic, Z. and Meda, P. (2012) Connexin-Dependent Signaling in Neuro-Hormonal Systems. Biochimica et Biophysica Acta, 1818, 1919-1936. http://dx.doi.org/10.1016/j.bbamem.2011.09.022

[12] Pfenniger, A., Chanson, M. and Kwak, B.R. (2013) Connexins in Atherosclerosis. Biochimica et Biophysica Acta, 1828, 157-166. http://dx.doi.org/10.1016/j.bbamem.2012.05.011

[13] Kwak, B.R., Mulhaupt, F., Veillard, N., Gros, D.B. and Mach, F. (2002) Altered Pattern of Vascular Connexin Expression in Atherosclerotic Plaques. Arteriosclerosis, Thrombosis, and Vascular Biology, 22, 225-230. http://dx.doi.org/10.1161/hq0102.104125

[14] Cigliola, V., Chellakudam, V., Arabieter, W. and Meda, P. (2013) Connexins and $\beta$-Cell Functions. Diabetes Research and Clinical Practice, 99, 250-259. http://dx.doi.org/10.1016/j.diabres.2012.10.016

[15] Wright, J.A., Richards, T. and Becker, D. (2012) Connexins and Diabetes. Cardiology Research and Practice, 2012, 496904. http://dx.doi.org/10.1155/2012/496904

[16] Tribulova, N., Knezl, V., Okruhlicova, L. and Slezak, J. (2008) Myocardial Gap Junctions: Targets for Novel Approaches in the Prevention of Life-Threatening Cardiac Arrhythmias. Physiological Research, 57, S1-S13.

[17] Carruba, G., Webber, M.M., Quader, S.T., Amoroso, M., Cocciadiferro, L., Saladino, F., Trosko, J.E. and Castagnetta, L.A. (2002) Regulation of Cell-to-Cell Communication in Non-Tumorigenic and Malignant Human Prostate Epithelial 
Cells. Prostate, 50, 73-82. http://dx.doi.org/10.1002/pros.10034

[18] Stein, E.A. (2001) New Statins and New Doses of Older Statins. Current Atherosclerosis Reports, 3, 14-18. http://dx.doi.org/10.1007/s11883-001-0005-z

[19] Pedersen, T.R. (2010) Pleiotropic Effects of Statins: Evidence against Benefits beyond LDL-Cholesterol Lowering. American Journal of Cardiovascular Drugs, 10, 10-17. http://dx.doi.org/10.2165/1158822-S0-000000000-00000

[20] Massy, Z.A. and Guijarro, C. (2001) Statins: Effects beyond Cholesterol Lowering. Nephrology, Dialysis, Transplantation, 16, 1738-1741. http://dx.doi.org/10.1093/ndt/16.9.1738

[21] de Barros, E.P., Garcia-Pinto, A.B., Machado, P.Y., dos Santos Pereira, M.J. and de Carvalho, J.J. (2011) Rosuvastatin Beneficially Alters the Glomerular Structure of Kidneys from Spontaneously Hypertensive Rats (SHRs). Journal of Molecular Histology, 42, 323-331. http://dx.doi.org/10.1007/s10735-011-9336-4

[22] Blackburn, J.P., Peters, N.S., Yeh, H.I., Rothery, S., Green, C.R. and Severs, N.J. (1995) Upregulation of Connexin43 Gap Junctions during Early Stages of Human Coronary Atherosclerosis. Arteriosclerosis, Thrombosis, and Vascular Biology, 15, 1219-1228. http://dx.doi.org/10.1161/01.ATV.15.8.1219

[23] van Kempen, M.J. and Jongsma, H.J. (1999) Distribution of Connexin37, Connexin40 and Connexin43 in the Aorta and Coronary Artery of Several Mammals. Histochemistry and Cell Biology, 112, 479-486. http://dx.doi.org/10.1007/s004180050432

[24] Wong, C.W., Christen, T., Roth, I., Chadjichristos, C.E., Derouette, J.P., Foglia, B.F., Chanson, M., Goodenough, D.A. and Kwak, B.R. (2006) Connexin37 Protects against Atherosclerosis by Regulating Monocyte Adhesion. Nature Medicine, 12, 950-954. http://dx.doi.org/10.1038/nm1441

[25] Wang, L.H., Chen, J.Z., Sun, Y.L., Zhang, F.R., Zhu, J.H., Hu, S.J. and Wang, D.H. (2005) Statins Reduce Connexin40 and Connexin43 Expression in Atherosclerotic Aorta of Rabbits. International Journal of Cardiology, 100, 467-475. http://dx.doi.org/10.1016/j.ijcard.2004.12.005

[26] Chadjichristos, C.E., Scheckenbach, K.E., van Veen, T.A., Richani Sarieddine, M.Z., de Wit, C., Yang, Z., Roth, I., Bacchetta, M., Viswambharan, H., Foglia, B., Dudez, T., van Kempen, M.J., Coenjaerts, F.E., Miquerol, L., Deutsch, U., Jongsma, H.J., Chanson, M. and Kwak, B.R. (2010) Endothelial-Specific Deletion of Connexin40 Promotes Atherosclerosis by Increasing CD73-Dependent Leukocyte Adhesion. Circulation, 121, 123-131. http://dx.doi.org/10.1161/CIRCULATIONAHA.109.867176

[27] Wang, L., Chen, J., Sun, Y., Zhang, F., Zhu, J., Hu, S. and Wang, D.H. (2005) Regulation of Connexin Expression after Balloon Injury: Possible Mechanisms for Antiproliferative Effect of Statins. American Journal of Hypertension, 18, 1146-1153.

[28] Gabriels, J.E. and Paul, D.L. (1998) Connexin43 Is Highly Localized to Sites of Disturbed Flow in Rat Aortic Endothelium but Connexin37 and Connexin40 Are More Uniformly Distributed. Circulation Research, 83, 636-643. http://dx.doi.org/10.1161/01.RES.83.6.636

[29] Kwak, B.R., Veillard, N., Pelli, G., Mulhaupt, F., James, R.W., Chanson, M. and Mach, F. (2003) Reduced Connexin43 Expression Inhibits Atherosclerotic Lesion Formation in Low-Density Lipoprotein Receptor-Deficient Mice. Circulation, 107, 1033-1039. http://dx.doi.org/10.1161/01.CIR.0000051364.70064.D1

[30] Hansson, G.K. (2005) Inflammation, Atherosclerosis, and Coronary Artery Disease. The New England Journal of Medicine, 352, 1685-1695. http://dx.doi.org/10.1056/NEJMra043430

[31] Rennick, R.E., Connat, J.L., Burnstock, G., Rothery, S., Severs, N.J. and Green, C.R. (1993) Expression of Connexin43 Gap Junctions between Cultured Vascular Smooth Muscle Cells Is Dependent upon Phenotype. Cell and Tissue Research, 271, 323-332. http://dx.doi.org/10.1007/BF00318619

[32] Lin, Y.C., Chiang, C.H., Chang, L.T., Sun, C.K., Leu, S., Shao, P.L., Hsieh, M.C., Tsai, T.H., Chua, S., Chung, S.Y., Kao, Y.H. and Yip, H.K. (2013) Simvastatin Attenuates the Additive Effects of TNF- $\alpha$ and IL-18 on the Connexin 43 Up-Regulation and Over-Proliferation of Cultured Aortic Smooth Muscle Cells. Cytokine, 62, 341-351. http://dx.doi.org/10.1016/j.cyto.2013.04.003

[33] Déglise, S., Martin, D., Probst, H., Saucy, F., Hayoz, D., Waeber, G., Nicod, P., Ris, H.B., Corpataux, J.M. and Haefliger, J.A. (2005) Increased Connexin43 Expression in Human Saphenous Veins in Culture Is Associated with Intimal Hyperplasia. Journal of Vascular Surgery, 41, 1043-1052. http://dx.doi.org/10.1016/j.jvs.2005.02.036

[34] Shen, J., Wang, L.H., Zheng, L.R., Zhu, J.H. and Hu, S.J. (2010) Lovastatin Inhibits Gap Junctional Communication in Cultured Aortic Smooth Muscle Cells. Journal of Cardiovascular Pharmacology and Therapeutics, 15, $296-302$. http://dx.doi.org/10.1177/1074248410373750

[35] Dubuis, C., May, L., Alonso, F., Luca, L., Mylonaki, I., Meda, P., Delie, F., Jordan, O., Déglise, S., Corpataux, J.M., Saucy, F. and Haefliger, J.A. (2013) Atorvastatin-Loaded Hydrogel Affects the Smooth Muscle Cells of Human Veins. The Journal of Pharmacology and Experimental Therapeutics, 347, 574-581. http://dx.doi.org/10.1124/jpet.113.208769

[36] Malewicz, B., Kumar, V.V., Johnson, R.G. and Baumann, W.J. (1990) Lipids in Gap Junction Assembly and Function. 
Lipids, 25, 419-427. http://dx.doi.org/10.1007/BF02538083

[37] Sheu, J.J., Tsai, T.H., Chang, L.T., Chiang, C.H., Youssef, A.A., Sun, C.K., Chang, N.K. and Yip, H.K. (2008) Diabetes Mellitus Downregulates Expression of Connexin43 in Rat Aortic Medial Smooth Muscle Cells and Can Be Reversed by Simvastatin and Losartan Therapy. Chang Gung Medical Journal, 31, 136-144.

[38] Hou, C.J., Tsai, C.H. and Yeh, H.I. (2008) Endothelial Connexins Are Down-Regulated by Atherogenic Factors. Frontiers in Bioscience, 13, 3549-3557. http://dx.doi.org/10.2741/2948

[39] Dlugosová, K., Weismann, P., Bernátová, I., Sotníková, R., Slezák, J. and Okruhlicová, L. (2009) Omega-3 Fatty Acids and Atorvastatin Affect Connexin 43 Expression in the Aorta of Hereditary Hypertriglyceridemic Rats. Canadian Journal of Physiology and Pharmacology, 87, 1074-1082. http://dx.doi.org/10.1139/Y09-104

[40] Tsai, C.H., Yeh, H.I., Tian, T.Y., Lee, Y.N., Lu, C.S. and Ko, Y.S. (2004) Down-Regulating Effect of Nicotine on Connexin43 Gap Junctions in Human Umbilical Vein Endothelial Cells Is Attenuated by Statins. European Journal of Cell Biology, 82, 589-595. http://dx.doi.org/10.1078/0171-9335-00348

[41] Yeh, H.I., Lu, C.S., Wu, Y.J., Chen, C.C., Hong, R.C., Ko, Y.S., Shiao, M.S., Severs, N.J. and Tsai, C.H. (2003) Reduced Expression of Endothelial Connexin37 and Connexin40 in Hyperlipidemic Mice: Recovery of Connexin37 after 7-Day Simvastatin Treatment. Arteriosclerosis, Thrombosis, and Vascular Biology, 23, 1391-1397. http://dx.doi.org/10.1161/01.ATV.0000083508.21989.15

[42] Hou, C.J., Tsai, C.H., Su, C.H., Wu, Y.J., Chen, S.J., Chiu, J.J., Shiao, M.S. and Yeh, H.I. (2008) Diabetes Reduces Aortic Endothelial Gap Junctions in ApoE-Deficient Mice: Simvastatin Exacerbates the Reduction. The Journal of Histochemistry and Cytochemistry, 56, 745-752. http://dx.doi.org/10.1369/jhc.2008.950816

[43] Vozzi, C., Dupont, E., Coppen, S.R., Yeh, H.I. and Severs, N.J. (1999) Chamber-Related Differences in Connexin Expression in Human Heart. Journal of Molecular and Cellular Cardiology, 31, 991-1003. http://dx.doi.org/10.1006/jmcc.1999.0937

[44] Coppen, S.R., Kodama, I., Boyett, M.R., Dobrzynski, H., Takagishi, Y., Honjo, H., Yeh, H.I. and Severs, N.J. (1999) Connexin45, a Major Connexin of the Rabbit Sinoatrial Node, Is Co-Expressed with Connexin43 in a Restricted Zone at the Nodal-Crista Terminalis Border. The Journal of Histochemistry and Cytochemistry, 47, 907-918. http://dx.doi.org/10.1177/002215549904700708

[45] Kim, E. and Fishman, G.I. (2013) Designer Gap Junctions that Prevent Cardiac Arrhythmias. Trends in Cardiovascular Medicine, 23, 33-38.

[46] Severs, N.J., Coppen, S.R., Dupont, E., Yeh, H.I., Ko, Y.S. and Matsushita, T. (2004) Gap Junction Alterations in Human Cardiac Disease. Cardiovascular Research, 62, 368-377. http://dx.doi.org/10.1016/j.cardiores.2003.12.007

[47] Anderson, K.P. (2003) Lipid-Lowering Therapy for Prevention of Ventricular Tachyarrhythmias. Journal of the American College of Cardiology, 42, 88-92. http://dx.doi.org/10.1016/S0735-1097(03)00497-2

[48] Bacova, B., Radosinska, J., Knezl, V., Kolenova, L., Weismann, P., Navarova, J., Barancik, M., Mitasikova, M. and Tribulova, N. (2010) Omega-3 Fatty Acids and Atorvastatin Suppress Ventricular Fibrillation Inducibility in Hypertriglyceridemic Rat Hearts: Implication of Intracellular Coupling Protein, Connexin-43. Journal of Physiology and Pharmacology, 61, 717-723.

[49] Liu, J., Zhang, H. and Nie, W. (2011) Effect of Pravastatin on Gap Junctions and Ventricular Arrhythmias in Rats with Myocardial Infarction. Journal of Clinical Cardiology, 27, 688-690.

[50] Zhang, A., Zhang, H. and Wu, S. (2010) Immunomodulation by Atorvastatin Upregulates Expression of Gap Junction Proteins in Coxsackievirus B3 (CVB3)-Induced Myocarditis. Inflammation Research, 59, 255-262. http://dx.doi.org/10.1007/s00011-009-0093-8

[51] Wu, S.Y. and Fang, H.Y. (2008) Effects of Pravastatin on Myocardial Connexin 43, IFN-Gamma and IL-10 Expressions in a Murine Model of Viral Myocarditis Induced by Coxsackievirus B3. Zhonghua Xin Xue Guan Bing Za Zhi, 36, 72-76.

[52] Sheu, J.J., Chang, L.T., Chiang, C.H., Sun, C.K., Chang, N.K., Youssef, A.A., Wu, C.J., Lee, F.Y. and Yip, H.K. (2007) Impact of Diabetes on Cardiomyocyte Apoptosis and Connexin43 Gap Junction Integrity: Role of Pharmacological Modulation. International Heart Journal, 48, 233-245. http://dx.doi.org/10.1536/ihj.48.233

[53] Laird, D.W. (2005) Connexin Phosphorylation as a Regulatory Event Linked to Gap Junction Internalization and Degradation. Biochimica et Biophysica Acta, 1711, 172-182. http://dx.doi.org/10.1016/j.bbamem.2004.09.009

[54] Celes, M.R., Torres-Dueñas, D., Alves-Filho, J.C., Duarte, D.B., Cunha, F.Q. and Rossi, M.A. (2007) Reduction of Gap and Adherens Junction Proteins and Intercalated Disc Structural Remodeling in the Hearts of Mice Submitted to Severe Cecal Ligation and Puncture Sepsis. Critical Care Medicine, 35, 2176-2185. http://dx.doi.org/10.1097/01.CCM.0000281454.97901.01

[55] Haefliger, J.A., Krattinger, N., Martin, D., Pedrazzini, T., Capponi, A., Döring, B., Plum, A., Charollais, A., Willecke, K. and Meda, P. (2006) Connexin43-Dependent Mechanism Modulates Renin Secretion and Hypertension. The Journal of 
Clinical Investigation, 116, 405-413. http://dx.doi.org/10.1172/JCI23327

[56] Chen, H.J., Yao, L., Chen, T.G., Yu, M., Wang, L.H. and Chen, J.Z. (2007) Atorvastatin Prevents Connexin43 Remodeling in Hypertrophied Left Ventricular Myocardium of Spontaneously Hypertensive Rats. Chinese Medical Journal, 120, 19021907.

[57] Zhang, F.Z., Wang, L., Zhang, C.T., Pu, J. and Chen, B. (2006) Effect of Atorvastatin on Gap Junction Remodeling in Hypertrophied Myocardium. China Journal of Modern Medicine, 16, 1145-1148.

[58] Zhang, W.Z., Song, Z.H., Chen, Y.Q., Ma, L., Li, D.D. and Hui, L.L. (2011) Effect of Atorvastatin on the Hypertrophy and Cx40 Expression of Atrial Myocytes Induced by Angiotensin II. Journal of Lanzhou University (Medical Sciences), 37, 15-19.

[59] Hagendorff, A., Schumacher, B., Kirchhoff, S., Lüderitz, B. and Willecke, K. (1999) Conduction Disturbances and Increased Atrial Vulnerability in Connexin40-Deficient Mice Analyzed by Transesophageal Stimulation. Circulation, 99, 1508-1515. http://dx.doi.org/10.1161/01.CIR.99.11.1508

[60] Wang, Z., Zhang, Y., Gao, M., Wang, J., Wang, Q., Wang, X., Su, L. and Hou, Y. (2011) Statin Therapy for the Prevention of Atrial Fibrillation: A Meta-Analysis of Randomized Controlled Trials. Pharmacotherapy, 31, 1051-1062. http://dx.doi.org/10.1592/phco.31.11.1051

[61] Osmak, M. (2012) Statins and Cancer: Current and Future Prospects. Cancer Letters, 324, 1-12. http://dx.doi.org/10.1016/j.canlet.2012.04.011

[62] Singh, S., Singh, P.P., Singh, A.G., Murad, M.H. and Sanchez, W. (2012) Statins Are Associated with a Reduced Risk of Hepatocellular Cancer: A Systematic Review and Meta-Analysis. Gastroenterology, 144, 323-332. http://dx.doi.org/10.1053/j.gastro.2012.10.005

[63] Bansal, D., Undela, K., D’Cruz, S. and Schifano, F. (2012) Statin Use and Risk of Prostate Cancer: A Meta-Analysis of Observational Studies. PLoS ONE, 7, Article ID: e46691, 1-11.

[64] Nielsen, S.F., Nordestgaard, B.G. and Bojesen, S.E. (2012) Statin Use and Reduced Cancer-Related Mortality. The New England Journal of Medicine, 367, 1792-1802. http://dx.doi.org/10.1056/NEJMoa1201735

[65] Demierre, M.F., Higgins, P.D., Gruber, S.B., Hawk, E. and Lippman, S.M. (2005) Statins and Cancer Prevention. Nature Reviews Cancer, 5, 930-942. http://dx.doi.org/10.1038/nrc1751

[66] Ruch, R.J., Madhukar, B.V., Trosko, J.E. and Klaunig, J.E. (1993) Reversal of ras-Induced Inhibition of Gap-Junctional Intercellular Communication, Transformation, and Tumorigenesis by Lovastatin. Molecular Carcinogenesis, 7, 50-59. http://dx.doi.org/10.1002/mc.2940070109

[67] Wei, N., Mi, M.T. and Zhou, Y. (2007) Influences of Lovastatin on Membrane Ion Flow and Intracellular Signaling in Breast Cancer Cells. Cellular \& Molecular Biology Letters, 12, 1-15. http://dx.doi.org/10.2478/s11658-006-0050-2

[68] Zhou, Y., Mi, M.T., Zhu, J.D. and Zhang, Q.Y. (2003) Effects of Lovastatin on Proliferation and Gap Junctional Intercellular Communication of Human Breast Cancer Cell MCF-7. Ai Zheng, 22, 257-261.

[69] Touraine, R.L., Vahanian, N., Ramsey, W.J. and Blaese, R.M. (1998) Enhancement of the Herpes Simplex Virus Thymidine Kinase/Ganciclovir Bystander Effect and Its Antitumor Efficacy in Vivo by Pharmacologic Manipulation of Gap Junctions. Human Gene Therapy, 9, 2385-2391. http://dx.doi.org/10.1089/hum.1998.9.16-2385

[70] Wang, L., Fu, Y., Peng, J., Wu, D., Yu, M., Xu, C., Wang, Q. and Tao, L. (2013) Simvastatin-Induced Up-Regulation of Gap Junctions Composed of Connexin 43 Sensitize Leydig Tumor Cells to Etoposide: An Involvement of PKC Pathway. Toxicology, 312, 149-157. http://dx.doi.org/10.1016/j.tox.2013.08.013

[71] Kandouz, M. and Batist, G. (2010) Gap Junctions and Connexins as Therapeutic Targets in Cancer. Expert Opinion on Therapeutic Targets, 14, 681-692. http://dx.doi.org/10.1517/14728222.2010.487866

[72] Leinonen, P., Aaltonen, V., Koskela, S., Lehenkari, P., Korkiamaki, T. and Peltonen, J. (2007) Impaired Gap Junction Formation and Intercellular Calcium Signaling in Urinary Bladder Cancer Cells Can Be Improved by Go6976. Cell Communication \& Adhesion, 14, 125-136. http://dx.doi.org/10.1080/15419060701557065

[73] Cesen-Cummings, K., Warner, K.A. and Ruch, R.J. (1998) Role of Protein Kinase C in the Deficient Gap Junctional Intercellular Communication of K-ras-Transformed Murine Lung Epithelial Cells. Anticancer Research, 18, 4343-4346.

[74] Danesh, F.R., Sadeghi, M.M., Amro, N., Philips, C., Zeng, L., Lin, S., Sahai, A. and Kanwar, Y.S. (2002) 3-Hydroxy-3Methylglutaryl CoA Reductase Inhibitors Prevent High Glucose-Induced Proliferation of Mesangial Cells via Modulation of Rho GTPase/ p21 Signaling Pathway: Implications for Diabetic Nephropathy. Proceedings of the National Academy of Sciences of the United States of America, 99, 8301-8305. http://dx.doi.org/10.1073/pnas.122228799

[75] Gupta, A., Gupta, V., Thapar, S. and Bhansali, A. (2004) Lipid-Lowering Drug Atorvastatin as an Adjunct in the Management of Diabetic Macular Edema. American Journal of Ophthalmology, 137, 675-682.

[76] Genetos, D.C., Zhou, Z., Li, Z. and Donahue, H.J. (2012) Age-Related Changes in Gap Junctional Intercellular Communication in Osteoblastic Cells. Journal of Orthopaedic Research, 30, 1979-1984. http://dx.doi.org/10.1002/jor.22172 